\title{
Debris flow hazards and emergency response in Taiwan
}

\author{
C.-Y. Chen ${ }^{1}$, W.-C. Lee ${ }^{1} \&$ F.-C. Yu ${ }^{2}$
}

${ }^{I}$ National Science and Technology Center for Disaster Reduction

(NCDR), Taipei, Taiwan, Republic of China

${ }^{2}$ National Chung-Hsing University, Taichung, Taiwan, Republic of China

\begin{abstract}
According to the field investigation by Soil and Water Conservation Bureau (SWCB) after the M7.6 Chi-Chi earthquake, there are 1,420 streams prone to initiating debris flow. The initiated slopeland related hazards are correlated to the geological conditions, topographic elevation, engineering design and human induced effects in addition to the strong seismic effects. The study summarized the debris flow and landslide hazards and their casual factors using field investigation of the post seismic hazards in Taiwan. The emergency responses of the National Science \& Technology Center for Disaster Reduction (NCDR) and governmental departments for typhoon induced flood and debris flow are introduced herein. Through the use of the active response mechanism, the casualties from typhoon-induced hazards are reduced and further enhancements for hazard mitigation by the hazard characteristics are suggested.
\end{abstract}

Keywords: debris flow, landslide, emergency response, Chi-Chi earthquake, Taiwan.

\section{Introduction}

According to statistics from the Central Weather Bureau, the total economic loss of typhoon induced natural hazards is estimated to be around 174 billion Taiwan dollars as an average each year from 1980 to 1998. Overall economic loss increased following the M7.6 Chi-Chi earthquake in 1999 until recent years. Typhoon Toraji (in 2001) caused a loss of 7,700 billion, Typhoon Nari cost (in 2001) 9,000 billion, and Typhoon Mindulle and the following storm (in 2004) resulted in 8,900 billion of economic loss. 
The study introduces the hazardous characteristics and tendency of debris flow hazards in Taiwan in recent years in order to enhance the research and strategy for hazard mitigations and lessen overall economic loss. The emergency responses of governmental departments and NCDR for typhoon-induced hazards are also included in this context.

\section{Debris flow hazards in Taiwan}

Table 1 summarizes the historical events initiating the severity of debris flow hazards in Taiwan from 1990 until recent years and the published number of debris flow prone creeks. In July 1996, Typhoon Herb hit Taiwan and brought $1,994 \mathrm{~mm}$ of rain causing 41 deaths from debris flow related hazards. Due to these catastrophic debris flow hazards, SWCB investigated and rated 485 debris flow prone creeks into low, medium and high grade according to their hazard potential for the purpose of public awareness.

Table 1: $\quad$ Events to initiate severity of debris flow hazards in Taiwan.

\begin{tabular}{|c|l|c|}
\hline Date & \multicolumn{1}{|c|}{ Event } & \multicolumn{1}{|c|}{$\begin{array}{c}\text { \# of death \& missing } \\
\text { from debris flow }\end{array}$} \\
\hline $1990 / 06$ & Typhoon Ofelia & 35 \\
\hline $1996 / 07$ & Typhoon Herb & 41 \\
\hline 1996 & SWCB published 485 debris flow prone creeks \\
\hline $\mathbf{1 9 9 9 / 0 9 *}$ & M7.6 Chi-Chi EQ \\
\hline 1999 & SWCB published 722 debris flow prone creeks \\
\hline $2000 / 11$ & Typhoon Xangsane & 8 \\
\hline $2001 / 07$ & Typhoon Toraji & 148 \\
\hline $2002 / 03$ & SWCB published 1,420 debris flow prone creeks \\
\hline $2004 / 07$ & $\begin{array}{l}\text { Typhoon Mindulle and the } \\
\text { following storm }\end{array}$ \\
\hline $2004 / 08$ & Typhoon Aere & 7 \\
\hline
\end{tabular}

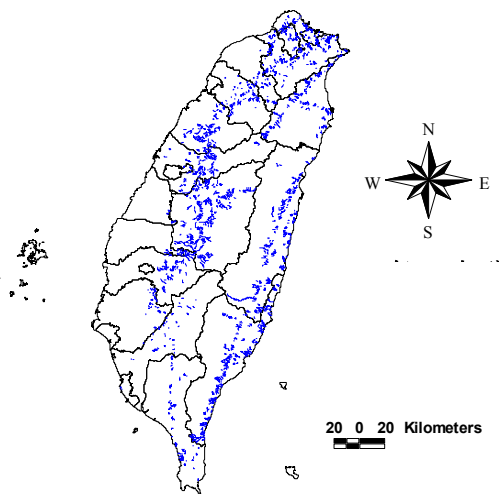

Figure 1: Locations of the 1,420 published debris flow prone creeks by SWCB in 2003. 
In 1999 the M7.6 Chi-Chi earthquake outbursts and debris flow hazards increased after the following rainstorms, for which SWCB re-investigated and re-published 720 debris flow prone creeks. Most of the increased debris flow prone creeks were located in the seismic affected areas. In July, 2001 Typhoon Toraji hit Taiwan and caused the most serious debris flow hazards ever seen, in which there were 148 deaths attributed to the debris flow hazards. Following this catastrophic debris flow hazard, the designated debris flow prone creeks were dramatically increased to 1,420 , as located and shown in Fig 1 . The loosened lithology in mountainous areas by the seismic shaking and eroded by subsequent torrential rains were attributed to the increased landslide and debris flow hazards (Dadson et al. [5]).

\section{Characteristics of debris flow hazards in Taiwan}

In addition to the trend of an extending of old seismic induced landslides by torrential rains, some common types of debris flow hazards occurring in recent years in Taiwan are presented herein.

\subsection{The formation of landslide dams}

There were two huge landslide dammed lakes that were formed after the seismic shaking of the Chi-Chi earthquake initiated landslides. These sequentially extended their exposed areas following the subsequent rainstorms. Fig. 2 shows the dip slope sliding at Chaolin township of $4 \mathrm{~km}^{2}$ in area and its landslide dammed lake (fig. 3) [3, 4]. Fig. 4 presents another dip slope failure at Jiufenershan township of $2 \mathrm{~km}^{2}$ in area [6,7] and its landslide-dammed lake (fig. $5)$.

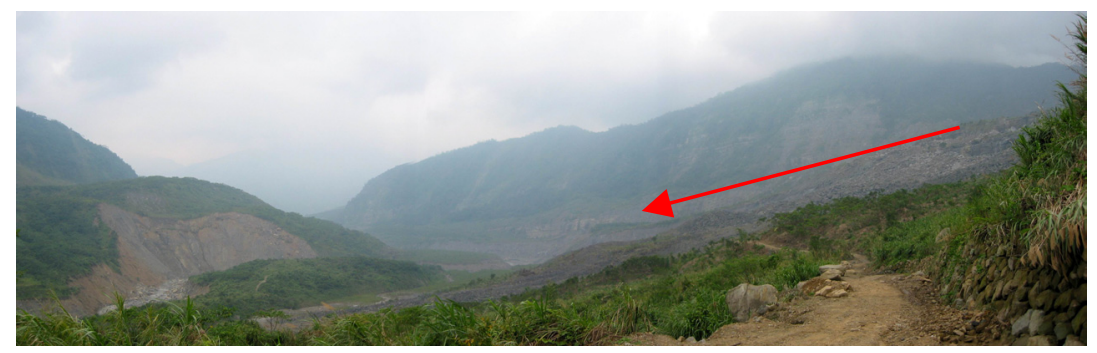

Figure 2: $\quad$ Seismic induced dip slope sliding in the Chaolin township (photo by C.-Y. Chen).

These landslide dams are prone to initiating debris flow once they have been breached. One case history of landslide dam breaching induced debris flow during Typhoon Xangsane in 2000 in northern Taiwan was presented by Chen et al. [1]. 


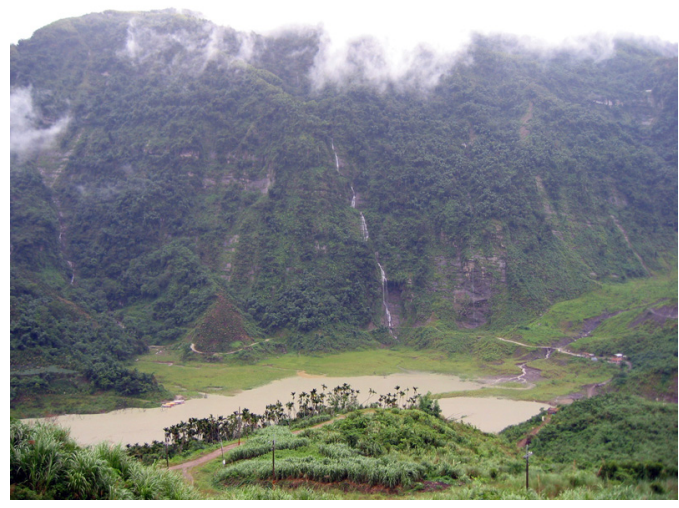

Figure 3: The landslide lake in the Chaolin township (photo by C.-Y. Chen).

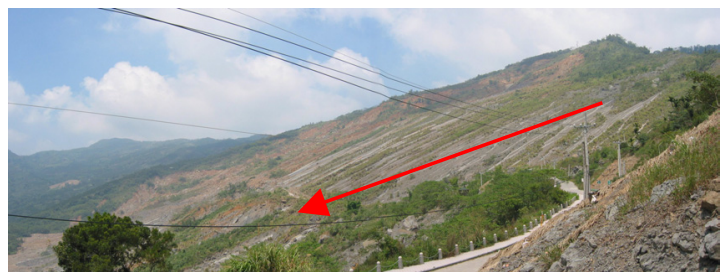

Figure 4: Seismic induced dip slope failure in the Jiufenershan township (photo by C.-Y. Chen).

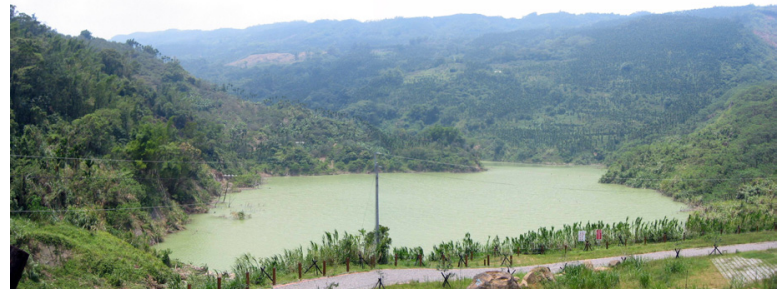

Figure 5: The dammed lake in the Jiufenershan township (photo by C.-Y. Chen).

\subsection{Repeated debris flows in specified areas}

Most of the repeated debris flows in history are located in the seismic affected areas in the middle of Taiwan. Fig. 6 shows one of the re-occurring debris flows in Chenyoulan river, Nantou County, in which the repeated debris flow was attributed to the abundant amount of debris in the streambed from the upland to the lower reaches. 


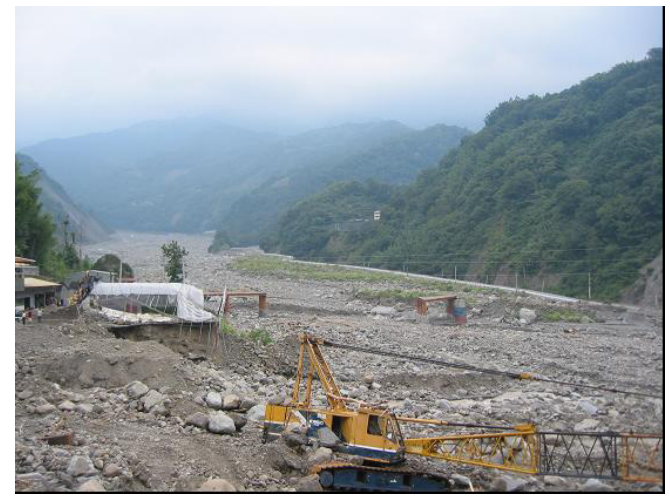

Figure 6: Repeated debris flow in the Chenyoulan river (photo by C.-Y. Chen).

\subsection{Upland slopeland hazards induced turbid water in reservoir}

Fig. 7 presents the turbid water and floating timbers in the Shihmen reservoir after Typhoon Mindulle. The silt accumulation induced turbid water sources from the upland landslides and streamside scouring by torrential rain stopping the outlet and jamming the water supply pipes for a couple of days. This event reoccurred after the rainstorms induced by Typhoon Aere, Haima in 2004 and Matsa in 2005.

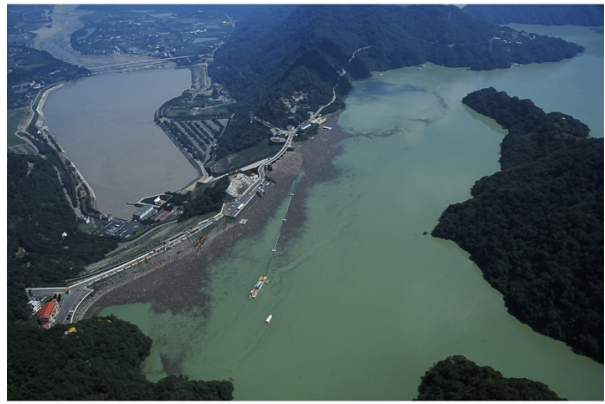

Figure 7: Turbid water and floating timbers from upland to the Shihmen reservoir following Typhoon Mindulle (photo by Council of Agriculture).

\subsection{The tendency to initiate massive debris flows}

Fig. 8 shows the debris flow hazards in Songher Tribute, Taichung County, when Typhoon Aere hit Taiwan in July, 2004. In this event, there were 43 houses buried by debris, and one further victim among the one thousand evacuated residents. This debris flow hazard originated from the Chi-Chi earthquake induced upland landslides and led to debris flow during Typhoon Aere and repeated hazards initiated by Haitang (in June) and Matsa (in Aug.) in 2005. 


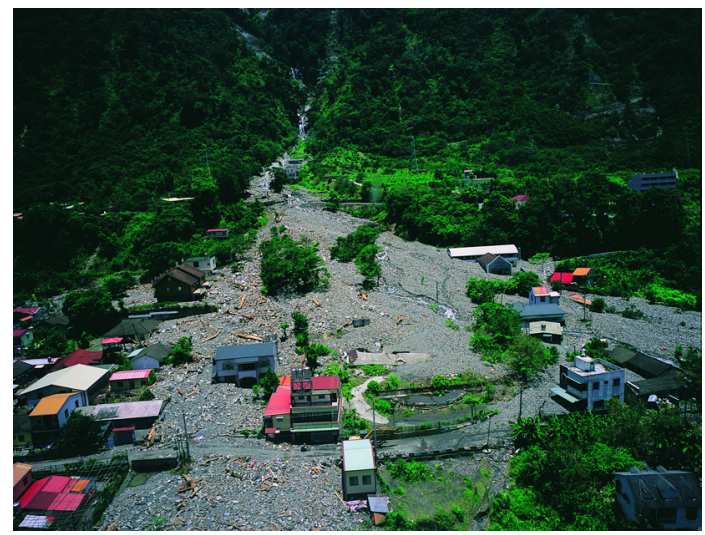

Figure 8: Debris flow hazard at Songher Tribute following Typhoon Mindulle (photo by Council of Agriculture).

\subsection{Sedimentary hazard from upland to downstream}

The Dajia river watershed, in the middle of Taiwan, suffered from torrential rains during Typhoon Mindulle in 2004 and the following rainstorms when Aere, Haima and Matsa in 2005 hit Taiwan. The severe seismic landslides in the upland during the Chi-Chi earthquake cut-off the traffic and the debris masses migrated to lower reaches during the torrential rains. The depositional masses raised the downstream riverbed and inundated the buildings on the riverside during the torrential rains (fig. 9).

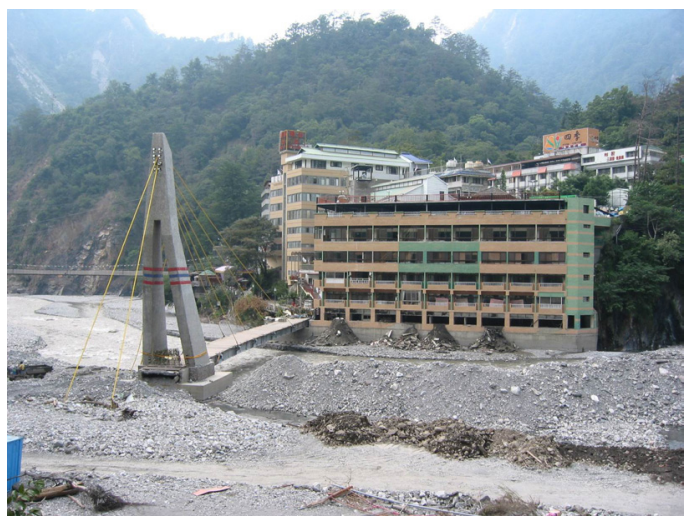

Figure 9: Deposited sediments at downstream of Dajia river following Typhoon Mindulle (photo by C.-Y. Chen).

\subsection{Isolated villages in off-track upland areas}

Fig. 10 shows the isolated village after Typhoon Mindulle induced torrential rains in the upland of Shihmen reservoir watershed. Most of the villages were 
cut-off because of landslides or debris flows from more than $1,000 \mathrm{~mm}$ of torrential rains in recent years.

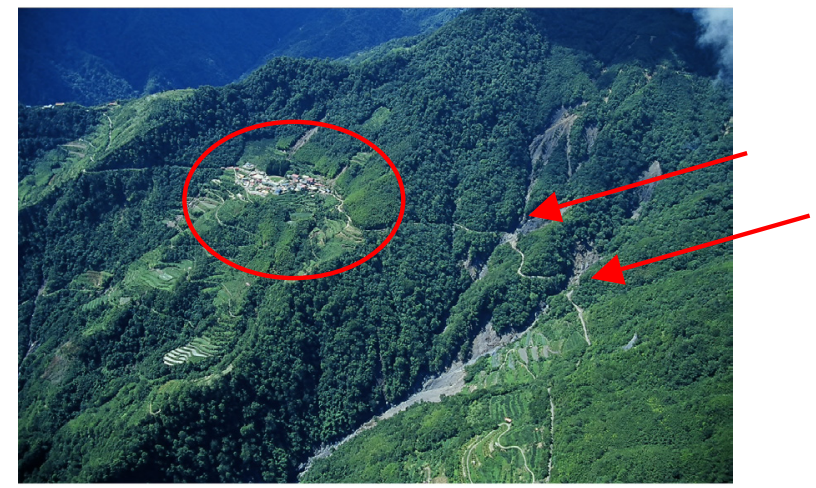

Figure 10: The isolated village after Typhoon Mindulle induced torrential rains in the upland area of the Shihmen reservoir watershed (photo by Council of Agriculture).

\subsection{Emergency response for hazard mitigation in Taiwan}

Fig. 11 shows the framework of the current disaster management organizational chart in Taiwan. The county and township levels of disaster prevention are coordinated by the Central Disaster Prevention \& Response Committee under the highest hazard management organization of the Central Disaster Prevention \& Preparedness Council. The Central Emergency Operation Center (CEOC) becomes active when a typhoon is going to hit Taiwan. An assessment group is organized in the CEOC to analyze the types of potential hazards and their locations. The members of the assessment group for typhoon-induced hazards are from the National Fire Agency, Central Weather Bureau, Water Resources Agency, SWCB, NCDR, and advisory specialists (fig. 12).

The emergency responses and countermeasures of the CEOC against typhoon-induced hazards include,

- pre-disposing and allocation of rescue resources for pre-warning areas,

- declaration of warning zones for potential hazards,

- pre-evacuation in high potential and repeated debris flow or flash flood areas,

- real-time rainfall monitoring for debris flow prone creeks during heavy rains,

- potential hazard analysis for flash floods, landslides and debris flows.

The actions of the department (SWCB) responsible for debris flow hazard emergency response include real-time rainfall monitoring, real-time field images feedback from 13 stations and two mobile stations, pre-community preparedness against any natural calamity, and pre-deployment of heavy machinery for emergency dredging in repeated debris flow creeks. 


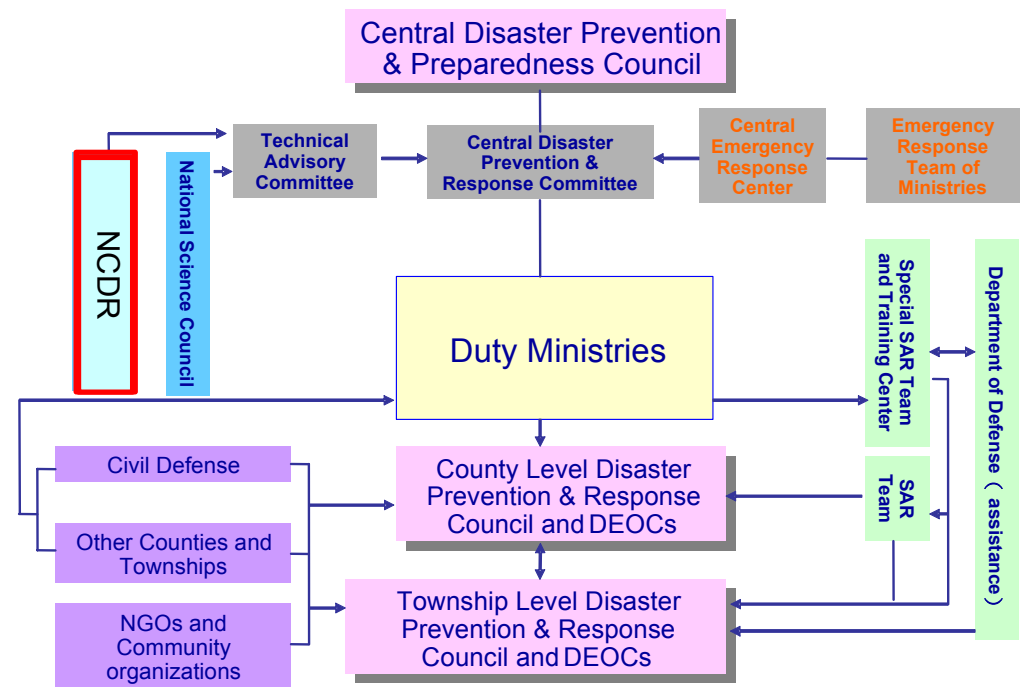

Figure 11: Framework of current disaster management organization in Taiwan (after the presentation of NCDR).

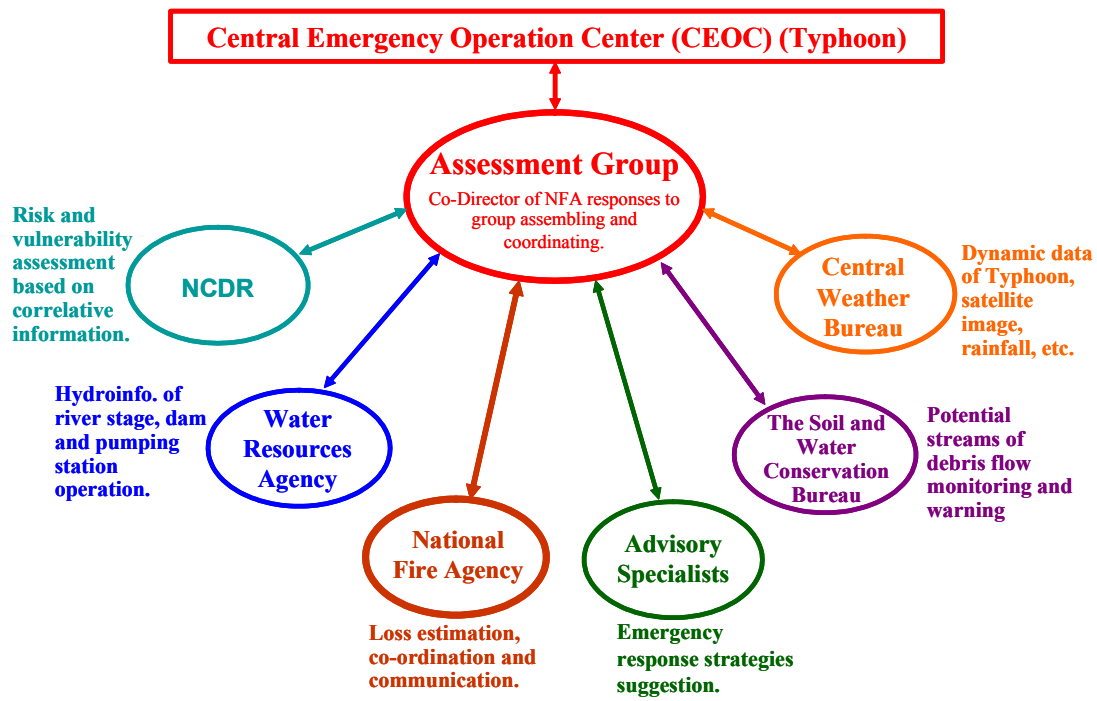

Figure 12: Operation of the CEOC Assessment Group (Typhoon) (after the presentation of NCDR).

The main action of NCDR in terms of emergency response is to provide technological advice, which includes actively working as an assessment group and supporting the CEOC in the event of a flash flood, landslide, debris flow and other possible hazards using the WebGIS decision support system (fig. 13, [2]). Through the use of the active emergency response, the casualties from debris flow hazards have fallen since 2001, as can be seen from table 2 . 


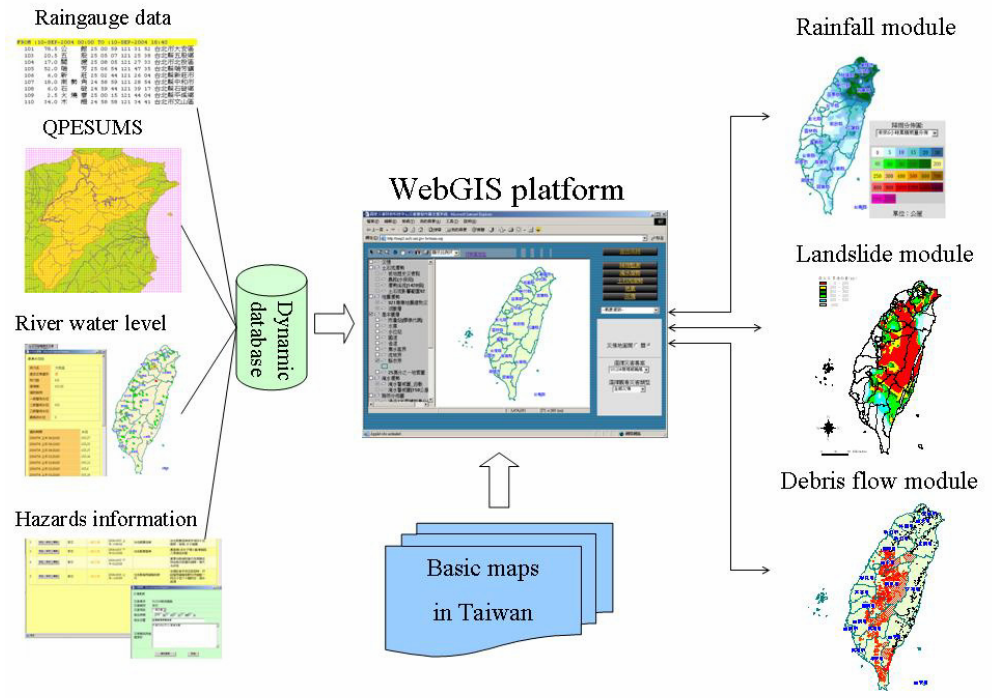

Figure 13: Framework of the NCDR's WebGIS decision support system for debris flow and landslide hazards warning (after Chen et al. [8]).

Table 2: $\quad$ Results of the active response against typhoon induced hazards.

\begin{tabular}{|l|c|c|c|c|c|}
\hline \multicolumn{1}{|c|}{ Events } & $\begin{array}{c}\text { Max. } \\
\text { Intensity } \\
(\mathrm{mm} / \mathrm{hr})\end{array}$ & $\begin{array}{c}\text { Accum. } \\
(\mathrm{mm})\end{array}$ & $\begin{array}{c}\# \text { of } \\
\text { Slopeland } \\
\text { Hazards* }\end{array}$ & $\begin{array}{c}\# \text { of } \\
\text { Evacuation } \\
\text { (person) }\end{array}$ & $\begin{array}{c}\text { Casualty } \\
\text { (person) }\end{array}$ \\
\hline Toraji (2001/07) & 147 & 757 & 673 & - & 214 \\
\hline Nari (2001/09) & 142 & 1,462 & 475 & 24,000 & 104 \\
\hline Mindulle (2004/06) & 167 & 2,005 & 1,023 & 9,500 & 41 \\
\hline Haitang (2005/07) & 177 & 2,124 & 605 & 1,208 & 15 \\
\hline
\end{tabular}

*source from SWCB, Directorate General of Highways, newspapers, and wireless news.

\section{Suggestions for further enhancement of debris flow hazard}

Mitigation strategies for slopeland hazards in off-track villages are urgently needed at this stage in Taiwan. The research studies concerned with emergency response and countermeasures at upland villages for debris flow hazards should include:

- planning of routes for emergency evacuation and rescue,

- planning of an active mechanism for real-time hazards investigation,

- planning of an active mechanism for emergency rescue,

- development of urgent repair technologies for landslide related road cut-off,

- revision of Soil and Water Conservation Acts and planning of land use and development of territory to accommodate the trend of hazards in recent years,

- enhancing the self-rescuing ability of residents and building up the Disaster Resistant Community. 


\section{Conclusion}

The Chi-Chi earthquake triggered severe landslides and initiated numerous debris flows after the following rainstorm. In review of the historical hazards, the main debris flow related hazardous characteristics are the depositional hazards at the lower reaches in seismic affected areas, cut-off roads at off-track upland areas, and deep seated massive land slides due to seepage. Planning of hazard mitigation strategies and enhancing self-rescue disaster resistance in off-track mountainous villages are urgently required in Taiwan.

\section{Acknowledgement}

Part of this work was supported by National Science Council under No. NSC942211-E-492-002. The financial support of NSC and the constructive suggestions by anonymous reviewers are acknowledged.

\section{References}

[1] Chen, C.Y., Chen, T.C., Yu, F.C., \& Hung, F.Y., A landslide dam breach induced debris flow - A case study on downstream hazard areas delineation. Environmental Geology, 47(1), pp. 91-101, 2004.

[2] Chen, C.Y., Yu, F.C., Lin, S.C., Lin, Y.Q., \& Wu, S.Y., A Web-based Decision Support System for Slopeland Hazards Warning. Submission to Environmental Monitoring \& Assessment, 2005.

[3] Chen, T.C., Lin, M.L., \& Hung, J.J., Pseudo static analysis of Tsao-Ling rockslide caused by Chi-Chi earthquake. Engineering Geology, 71(1-2), pp. 31-47, 2004.

[4] Chigira, M., Wang, W.N., Takahiko, F.T., \& Toshitaka, K.T., Geological causes and geomorphological precursors of the Tsaoling landslide triggered by the 1999 Chi-Chi earthquake, Taiwan. Engineering Geology, 68, pp. 259-273, 2003.

[5] Dadson, S.J., Hovius, N., Chen H., Dade, W.B., Lin, J.C., Hsu, M.L., Lin, C.W., Horng, M.J., Chen T.C., Milliman, J., \& Stark, C.P., Earthquaketriggered increase in sediment delivery from an active mountain belt. Geology, 32, pp. 733-736, 2004.

[6] Shou. K.J., \& Wang. C.F., Analysis of the Chiufengershan landslide triggered by the 1999 Chi-Chi earthquake in Taiwan. Engineering Geology, 68, pp. 237-250, 2003.

[7] Wu, J.H., Wang, W.N., Chang, C.S., \& Wang, C.L., Effects of strength properties of discontinuities on the unstable lower slope in the Chiu-fenerh-shan landslide, Taiwan. Engineering Geology, 78, pp. 173-186, 2005.

[8] Yu F. C., Chen C. Y., Lin S. C., Lin Y. Q., Wu S. Y., Cheung K. W., 2006."A Web-based Decision Support System for Slopeland Hazards Warning." Environmental Monitoring and Assessment (Accept). 